\title{
The Effect of Compensation towards Civil Servant Employees Performance on Department of Unity and Politic City of Palangka Raya
}

\author{
Suryadinata ${ }^{1}$, Laksminarti ${ }^{2}$ \\ Universitas Muhammadiyah Palangkaraya, Jalan RTA. Milono, KM. 1,5 \\ Pahandut Palangka Raya, Kalimantan Tengah-731111,2 \\ \{suryadinatapp13@gmail.com¹, laksminarti@gmail.com²\}
}

\begin{abstract}
This study aims to identify compensation, application, identify performance and analyze the effect of compensation on the Performance of Civil Servants in the National Unity and Politics Board of the City of Palangka Raya. The population in this study amounted to 40 people, with a sample of 29 people. The results of this study focus on Compensation because it is important for Civil Servants and it is found that compensation has a positive and significant effect on employee performance. Compensation is a reward given by the organization to its employees, either financial or non-financial, as a form of appreciation for the performance of employees who have been achieved in order to achieve organizational goals. Between the two variables, financial compensation has a more dominant influence on employee performance than non-financial compensation.
\end{abstract}

Keywords: Compensation, Performance

\section{Introduction}

The era of globalization is an era of development, where the key to the competition is human quality resources who are able to compete and bring positive impact for both the organizations and themselves.

Therefore, human resource development must be the center of attention because it is the subject and object of development. However, the fact shows that the abundant number of labor force at a fast growth rate is actually the main problem of employment in Indonesia. Hence, the government needs to pay attention to the welfare of the employees so that they can work well and enthusiastically, and truly feel satisfied in carrying out their work activities and service to the community will be maximized. Someone works expecting remuneration or rewards for the results of his work. The remuneration received by civil servants is known as compensation.

Compensation is the right of a PNS (Civil Servant) which has been determined in the laws, regulations. Palangka Raya Mayor Regulation Number 37 of 2017 concerning Regional Performance Allowances in the Palangka Raya City Government Environment in 2018 [1]. With the compensation given to the employees, it is hoped that it can improve the work ethic and discipline of employees in carrying out their duties. 
Behavior arising from PNS (Civil Servant) towards government agencies is related to the satisfying needs, for example compensation obtained after work. By the existence of compensation, most of one's needs can be fulfilled, both physical and non-physical needs, as well as safety and health insurance at work.

Therefore, it is closely depends on the satisfaction of the compensation needs received by civil servants, hence compensation is the dominant element in influencing the performance of civil servants (civil servants). Employee behavior or performance will deal with wise efforts and certain conditions desired as for results to be achieved. For example, the level of work discipline of the employee, the level of absenteeism, employee loyalty to the organization and the organization where he has an idea.

A leader can be said to be successful in motivating employees can be seen from the behavior and attitudes of employees towards the work they do, namely whether they work seriously, enthusiastically and do not forced to carry out their duties, honest and responsible. In improving employee performance, employees who work efficiently are needed. This is aimed to save time in carrying out their duties and increasing employee discipline.

In order to achieve the expected goals of an organization (government agency), an employee (PNS) must be given a motivation such as fulfilling the needs and the desires of employees which can be done by giving high wages, providing targeted incentives, and even giving rewards to employees who excel.

According to Andrew E. Sikula in his book Hasibuan [2] says that the process of wage or salary administration (sometimes called compensation) involves consideration or balance calculation. Compensation is something that is considered as an equivalent. In employment, gifts in the form of money are compensation given to employees as a reward for their service. The forms of wages and salaries are used to regulate the provision of finance between the organization and employees. Giving wages is a reward, payment for services provided by employees. The payment can be in the form of money (financial) or in the form of non-money (non-financial). Compensation is very important for employees.

The existence of human resources in a Regional Apparatus Organization Unit (SOPD) plays a very important role. Civil servants have great potential to carry out government activities. The potential of each human resource in the agency must be utilized as well as possible so as to provide optimal work results and services. The achievement of the vision and mission that has been set by an SOPD does not only depend on modern equipment, complete facilities and infrastructure, but also depends more on the existence of the personnel who carry out the work

The success of an SOPD is greatly influenced by the performance of individuals and groups of civil servants. Each SOPD will always strive to improve the performance of its personnel in the hope that what the organizational goals will be achieved and the expected goals of SOPD will be achieved, so a civil servant must be given a motivation such as meeting the needs and desires of employees which, among others, can be done by providing high wages., provide targeted incentives, and even give awards or rewards to employees who excel.

To do a certain job, someone must expect results or remuneration from the work he does. Employees must be rewarded for the effort they have put into achieving the goals of the organization and their own goals. Usually the result of remuneration is given in the form of compensation. Compensation can be more than just wages and salaries. In compensation, it can also include incentives / incentives and employee benefits and service programs that can increase productivity [3]. The objectives to be achieved in this research are to:

a) Identifying the financial compensation applied by the National Unity and Political Body of Palangka Raya City. 
b) Identifying the non-financial compensation applied by the National Unity and Political Body of Palangka Raya City.

c) Analyzing the effect of compensation on the performance of the Palangka Raya City Political and National Unity Agency employees.

According to Rivai [4] compensation is something that employees receive as a substitute for their service contribution to the company. Compensation according to Handoko [5] is everything that employees receive in return for their work.

Basically, compensation is classified into two groups, namely financial compensation and non-financial compensation. Furthermore, some financial compensation is direct and some is indirect. Meanwhile, non-financial compensation can be in the form of work and work environment. According to Sofyandi [6] financial compensation is compensation given to employees in exchange for work done for the company. Sutrisno [7] states that financial compensation is compensation that is directly submitted by a company to its employees in the form of wages or bonuses. Panggabean [8] argues that financial compensation consists of salaries, allowances, and incentives.

Apart from compensation in the form of financial, compensation is also in non-financial form. According to Sutrisno [7] non-financial compensation is compensation that cannot be felt directly by employees. Rivai [9] states that non-financial compensation consists of company facilities, praise, feeling comfortable at work, opportunities for promotion, motivation from the company, the work environment. According to Sofyandi [6] non-financial compensation is the provision of compensation to employees as a company effort to improve the welfare of its employees. From the opinions of several experts above, the authors conclude that non-financial compensation is compensation provided by the company to its employees regardless of one employee or another. Non-financial compensation is used by companies to improve the welfare of their employees so that they are comfortable at work.

A successful company cannot be separated from the performance of the employees who work for the company. Performance according to Mangkunegara [10] is the quality and quantity of work achieved by an employee in carrying out his duties according to the responsibilities assigned to him. In addition, according to Sedarmayanti [11] performance is the work of an employee, a management process as a whole, where the results of a person's work must be shown concrete and measurable evidence. According to Mangkunegara [12], performance is the result of work in quality and quantity achieved by an employee by carrying out his duties in accordance with the responsibilities assigned to him.

Based on several studies and theoretical studies, a research concept framework can be prepared as shown in Picture 1.

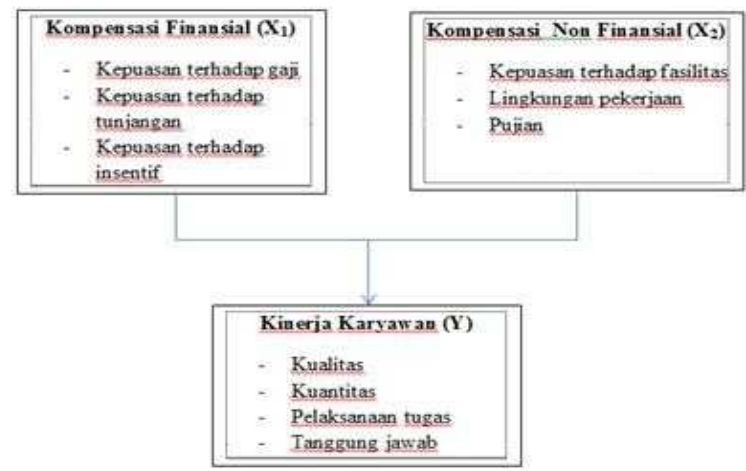

Fig. 1. Research Framework 
Hypothesis:

Ha1 : Financial Compensation has a positive effect on Employee Performance in the National Political Unity Agency of Palangka Raya City

Ha2 : Non-financial compensation has a positive effect on employee performance in the National Political Body of Palangka Raya City

\section{Methodology}

This research approach is a quantitative research method with a descriptive approach. Quantitative research methodology with a descriptive approach is a scientific method for obtaining valid data with the aim of being able to find, prove and develop knowledge so that in turn it can be used to understand, solve and anticipate problems in certain fields and describe them in numerical form which are then interpreted [13]. In this study, the case study focuses on the effect of compensation on the improvement of employee performance in the office of the National Unity and Political Body of the City of Palangka Raya.

This study aims to determine the effect of financial compensation (X1) and non-financial compensation $(\mathrm{X} 2)$ on employee performance $(\mathrm{Y})$. The research object in this research is financial compensation, non-financial compensation, and employee performance. Population is a combination of all elements in the form of events, things or people who have similar characteristics that become the center of attention of a researcher because it is seen as a research universe [14]. The population in this study were 40 Civil Servants and Contractors of the National Unity and Political Body of Palangka Raya City.

Based on the Slovin formula [15], the number of samples obtained was 40 people, the number of respondents obtained was 29 people, with details of Echelon III: 5 respondents out of 5 people, Echelon IV: 11 respondents from 11 people and 13 respondents as implementers of 23 people. The sampling technique used was simple random sampling, this technique is a way of taking samples without selecting individuals who will be members of the sample. The type of data used by the authors in this study is primary data. According to Lungan [16] primary data is data that is directly obtained from the field through experiments, surveys and observations. In this case, the data were obtained through a questionnaire distribution process.

The data collection method used was a questionnaire or questionnaire. A questionnaire or questionnaire is a way of collecting data by giving written questions that will be answered by respondents, so that researchers obtain field / empirical data to solve research problems and test predetermined hypotheses. The data analysis technique used consists of the validity test, reliability test, descriptive analysis, classical assumption test, multiple linear regression, goodness of fit which consists of the $\mathrm{F}$ test and $\mathrm{t}$ test, and the coefficient of determination (Rsquare). Data processing using SPSS assistance.

\section{Result and Discussion}

\subsection{Data Analysis}

Descriptive analysis is used to describe data from respondents' answers regarding financial compensation, non-financial compensation, and employee performance. Descriptive responses of respondents will be based on the distribution of respondents' answers and the mean value for each question indicator and for each variable. 
Table 1. Decription of Data Validity

\begin{tabular}{lccccc}
\hline \multicolumn{5}{c}{ Variable } & \multicolumn{5}{c}{ Validity Test } \\
\hline Financial Compensation $\left(\mathrm{X}_{1}\right)$ & $\mathrm{X}_{1.1}$ & 1,6151 & $>$ & 0,3673 & VALID \\
& $\mathrm{X}_{1.2}$ & 1,6116 & $>$ & 0,3673 & VALID \\
& $\mathrm{X}_{1.3}$ & 1,6164 & $>$ & 0,3673 & VALID \\
Non Financial Compensation $\left(\mathrm{X}_{2}\right)$ & $\mathrm{X}_{2}$ & 1,6156 & $>$ & 0,3673 & VALID \\
& & & & & \\
Performance $(\mathrm{Y})$ & $\mathrm{Y}_{1.1}$ & 1,6121 & $>$ & 0,3673 & VALID \\
& $\mathrm{Y}_{1.2}$ & 1,5798 & $>$ & 0,3673 & VALID \\
& $\mathrm{Y}_{1.3}$ & 1,6122 & $>$ & 0,3673 & VALID \\
& $\mathrm{Y}_{2.1}$ & 1,6119 & $>$ & 0,3673 & VALID \\
& $\mathrm{Y}_{2.2}$ & 1,61103 & $>$ & 0,3673 & VALID \\
& $\mathrm{Y}_{3.1}$ & 1,6124 & $>$ & 0,3673 & VALID \\
& $\mathrm{Y}_{3.2}$ & 1,6113 & $>$ & 0,3673 & VALID \\
\hline
\end{tabular}

Multiple Linear Equations

$$
\begin{aligned}
& Y=a X^{1}+b X^{2} \\
& Y=0,1885 X_{1}+0,1896 X_{2}
\end{aligned}
$$

That the Linear Equation as mentioned above, can be interpreted as follows:

a) The regression coefficient for the variable X1 (Financial Compensation) is positive at 0.1885 . This shows that there is a positive influence between financial compensation and employee performance and it means that if the compensation variable is increased, the performance will also increase.

b) The regression coefficient X2 (Non-Financial Compensation) is positive at 0.1896. This shows that there is a positive influence between non-financial compensation and employee performance and it means that if the non-financial compensation variable is increased, the performance will also increase.

That the significant value of the $t$ test as mentioned above, shows significantly the effect of compensation on performance. The test is by comparing the probability value of $\mathrm{T}$ with a probability of 0.05 and states that the compensation variable has a positive influence on the performance variable which can be seen by paying attention to the value of the construct coefficient of 0.60 . If the probability value of $\mathrm{T}>0.05$, the hypothesis is accepted. And, based on the data in Table 4:22, it is concluded that: Compensation $(\mathrm{X})$ with a significant $0.000>$ 0.05 , so it is evident that the compensation variable has an effect on the performance variable (Y).

Because it has a t count greater than 1.703 , it can be concluded that compensation has a positive and significant effect on performance. This shows that the compensation received by the employees of the National Unity and Political Body of Palangka Raya City is quite good and still needs to be improved, so that this becomes motivation for employees to work and produce good performance.

\section{a) The Effect of Financial Compensation on Performance}

Financial compensation has a contribution to performance with a T-count value of 5.026 (positive value) on performance with a compensation construct coefficient of 0.60 . This 
contribution shows that financial compensation has a positive and significant effect on employee performance. Financial compensation provided at the National Unity and Political Body of Palangka Raya City, such as salaries, and incentives / regional performance allowances, which are given to encourage employees to work optimally, so that the resulting performance is optimal. This is evident because financial compensation has a positive and significant effect on employee performance.

\section{b) The Effect of Non-Financial Compensation on Performance}

Non-financial compensation has a contribution to performance with a T-count value of 4.5973 (positive value) on performance with a compensation construct coefficient of 0.60. This contribution shows that financial compensation has a positive and significant effect on employee performance. Compensation given to the National Unity and Political Body of Palangka Raya City, such as health insurance, pension funds, interesting tasks and according to regulations, work that is full of challenges, rewarded work results, rewards according to performance, policies applied, colleagues who are competent and pleasant and a comfortable work environment has encouraged employees to work optimally in order to achieve optimal performance.

\section{c) Employee Performance of the National Unity and Political Body of Palangka Raya City}

Performance appraisal of the National Unity and Political Body of Palangka Raya City based on Employee Work Goals (SKP) consisting of loyalty, work performance, responsibility, obedience, honesty, cooperation, initiative, and leadership. This is indicated by the T-count value of 6.854 against the construct coefficient of 0.60 .

\section{Conclusion}

a) The National Unity and Political Body of Palangka Raya City provides financial compensation such as salaries, incentives / regional performance allowances. Nonfinancial compensation such as health insurance, pension funds, facilities, praise / appreciation. Most of the employees are quite satisfied with the compensation given, but it still needs to be increased.

b) Performance appraisal at the National Unity and Political Body of Palangka Raya City based on Employee Work Goals (SKP) consisting of loyalty, work performance, responsibility, obedience, honesty, cooperation, initiative, and leadership. In general, the performance of the employees of the National Unity and Political Body of the City of Palangka Raya has been good.

c) Compensation has a positive and significant impact on the performance of the employees of the Bogor City Regional Revenue Service with a construct coefficient level of 0.60 (positive) and a significance value of 5, 026 and 4.5973, greater than 1.703. Therefore, it can be concluded that if the compensation is increased, it will improve the performance of the employees of the National Unity and Political Body of Palangka Raya City. 


\section{References}

[1] Palangka Raya Mayor Regulation Number 37 of 2017 concerning Regional Performance Allowances in the Palangka Raya City Government Environment in 2018

[2] Hasibuan, Malayu. 2002. Human Resource Management. Earth Literacy. Jakarta

[3] Justine T. Sirait, 2006, Understanding the Aspects of Human Resource Management in Organizations. Jakarta: PT Grasindo.

[4] Rivai, Veithzal. 2005. Human Resource Management For Companies From Theory To Practice. Jakarta: PT. Raja Grafindo Persada

[5] Handoko, T. Hani. 2008. Human Resources Personnel Management. Second Edition. Yogyakarta: BPFE Publisher

[6] Sofyandi, Herman. 2008. Human Resource Management. Yogyakarta: Graha Science.

[7] Sutrisno, Edi. 2009. Human Resource Management First edition. Jakarta: Kencana Prenada Media Group

[8] Panggabean, S. Mutiara. 2004. Human Resource Management. Bogor: Ghalia Indonesia

[9] Rivai, Veithzal. 2004. Human Resource Management for Companies. First Printing, Jakarta: PT. Raja Grafindo Persada

[10] Mangkunegara, A.A. Anwar Prabu. 2009. Human Resource Management. Bandung: Youth Rosdakarya.

[11] Sedarmayanti. 2011. Human Resource Management, Bureaucratic Reform and Civil Servant Management (Fifth Printing), Bandung: PT. Refika Aditama

[12] Mangkunegara. 2011. Company Resource Management. PT. Rosdakarya youth. Bandung.

[13] Sugiyono. 2004. Research Methods. Bandung: Alfabeta

[14] Ferdinand, Zaviera. 2007. Fidel Castro Revolution to Death. Jogjakarta: Garage.

[15] Husein, Umar. (2004). Human Resources Research in Organizations, Gramedia Pustaka, Jakarta.

[16] Lungan, R. 2006. Applications of Statistics and Calculate Opportunities. First Edition. Graha Ilmu, Jakarta. 